\title{
STUDI KELAYAKAN PENDIRIAN INDUSTRI KECIL PUPUK ORGANIK PADAT DAN CAIR BERBAHAN BAKU LIMBAH PERKEBUNAN, PETERNAKAN DAN INDUSTRI
}

\author{
Rizki Wahyuniardi dan Eeng Sumarna \\ Program Studi Teknik Industri, Universitas Pasundan \\ e-mail: rizki.wahyuniardi@unpas.ac.id; eengsumarna@yahoo.co.id
}

\begin{abstract}
ABSTRAK
Pengembangan industri kecil yang mampu membuat pupuk organik adalah mendukung pertanian organik dan menjawab persoalan kerusakan lahan pertanian. Penggunaan pupuk kimia secara terus-menerus menjadi penyebab menurunnya kesuburan lahan bila tidak diimbangi dengan penggunaan pupuk organik dan hayati. Penelitian Lembaga Penelitian Tanah (LPT) Bogor menunjukkan 79 \% tanah sawah dan areal perkebunan di Indonesia memiliki Bahan Organik (BO) yang sangat rendah $(B O<1)$. Kondisi ini bermakna bahwa tanah sawah di Indonesia memerlukan penyembuhan. Penyembuhan dilakukan dengan menambahkan BO yang telah diolah menjadi pupuk organik sehingga tanah dapat menjadi lebih sehat dengan kandungan BO 3-4 \%. Penelitian ini menguraikan studi kelayakan pengembangan industri kecil pupuk organik dari limbah padat maupun cair yang telah dilakukan. Sesuai dengan bahan baku yang dibutuhkan, pabrik pembuatan pupuk organik padat dan cair disesuaikan dengan sumber lokasi bahan baku. Hasil penelitian menunjukkan bahwa pendirian industri kecil ini sangat layak untuk dikembangkan dengan nilai IRR sebesar 97\% dan 99\% untuk pendirian industri kecil pupuk organik padat dan cair.
\end{abstract}

Kata Kunci: Pupuk Organik Padat, Pupuk Organik Cair, Kelayakan Bisnis

\begin{abstract}
The development of organic fertilizer small industries is to support organic farming and answer the degradation of agricultural land. The use of chemical fertilizers continuously into the causes of declining soil fertility if not offset by the use of organic fertilizers. Lembaga Penelitian Tanah (LPT) at Bogor showed $79 \%$ of paddy and plantation land in Indonesia has Organic Materials (OM) is very low $(O M<1)$. This condition means that the Indonesian rice field in need of healing. Healing is done by adding the BO that has been processed into organic fertilizer to the soil can become healthier with BO content of 3-4\%. This study outlines the feasibility study of the development of small industrial organic fertilizer from solid or liquid waste that has been done. In accordance with the required raw materials, factory manufacture solid and liquid organic fertilizer tailored to the location of the source of raw materials. The results showed that the establishment of small industries is very feasible to be developed with the value of IRR of $97 \%$ and $99 \%$ for the establishment of small industrial solid and liquid organic fertilizer.
\end{abstract}

Keywords: Solid Organic Fertilizer, Liquid Organic Fertilizer, Business Feasibility

\section{PENDAHULUAN}

Memasuki abad 21 ini, gaya hidup sehat dengan slogan "Back to Nature” telah menjadi trend baru masyarakat dunia. Orang makin menyadari bahwa penggunaan bahan-bahan kimia non-alami, seperti pupuk dan pestisida kimia sintetis serta hormon tumbuhan, dalam produksi pertanian ternyata berdampak negatif terhadap kesehatan manusia dan lingkungan hidup. Gaya hidup yang demikian ini telah mengalami pelembagaan secara internasional yang diwujudkan melalui regulasi perdagangan global yang mensyaratkan jaminan bahwa produk pertanian harus mempunyai atribut aman dikonsumsi (food safety attributes), memiliki kandungan nutrisi tinggi (nutritional attributes) serta ramah lingkungan (ecolabelling attributes) [1].

Salah satu alasan pentingnya pengembangan pertanian organik adalah persoalan kerusakan lahan pertanian yang semakin parah. Penggunaan pupuk kimia secara terus-menerus menjadi penyebab menurunnya kesuburan lahan bila tidak diimbangi dengan penggunaan pupuk organik dan pupuk hayati. Hasil penelitian LPT menunjukkan bahwa $79 \%$ tanah sawah di Indonesia memiliki Bahan Organik (BO) yang sangat rendah $(\mathrm{BO}<1)$. Kondisi ini bermakna bahwa tanah sawah di Indonesia sudah sangat miskin bahkan bisa dikatakan sakit, sehingga tidak hanya membutuhkan makanan (pupuk kimia), namun 
juga memerlukan penyembuhan. Cara penyembuhan adalah dengan menambahkan BO yang telah diolah menjadi pupuk organik, sehingga tanah dapat menjadi lebih sehat dengan kandungan BO sekitar 3-4 \%. Untuk meningkatkan kandungan $\mathrm{BO}$, maka dibutuhkan tambahan bahan-bahan organik (pupuk organik) berkisar 5-10 ton/ha. Namun demikian, peningkatan kandungan BO pada setiap hektar tanah sawah dapat dilakukan secara bertahap dengan memberikan asupan pupuk organik pada kisaran 3-5 ton [1].

\section{TINJAUAN PUSTAKA}

Pupuk organik adalah nama kolektif untuk semua jenis bahan organik asal tanaman dan hewan yang dapat dirombak menjadi hara tersedia bagi tanaman. Dalam Permentan No.2/Pert/Hk.060/2/2006, tentang Pupuk Organik dan Pembenah Tanah, dikemukakan bahwa pupuk organik adalah pupuk yang sebagian besar atau seluruhnya terdiri atas bahan organik yang berasal dari tanaman dan atau hewan yang telah melalui proses rekayasa, dapat berbentuk padat atau cair yang digunakan mensuplai bahan organik untuk memperbaiki sifat fisik, kimia, dan biologi tanah. Definisi tersebut menunjukkan bahwa pupuk organik lebih ditujukan kepada kandungan C-organik atau bahan organik daripada kadar haranya; nilai C-organik itulah yang menjadi pembeda dengan pupuk anorganik. Bila C-organik rendah dan tidak masuk dalam ketentuan pupuk organik maka diklasifikasikan sebagai pembenah tanah organik. Pembenah tanah atau soil ameliorant menurut SK Mentan adalah bahan-bahan sintesis atau alami, organik atau mineral [2].

Potensi pasar pupuk organik di Indonesia sangat tinggi baik untuk tanaman pangan maupun tanaman hortikultura. Dari hasil penelitian Puslit Tanah tentang status C-Organik lahan sawah di Indonesia terutama di daerah Sumatera Barat, Sumatera Selatan, Jawa Barat, Jawa Tengah, Jawa Timur, Kalimantan, NTB, dan Sulawesi Selatan menunjukkan potensi kebutuhan pupuk organik yang sangat besar. Untuk tanaman pangan di daerah-daerah tersebut dengan luas lahan sekitar 5,9 juta ha membutuhkan sekitar 3 juta ton, sedangkan untuk tanaman hortikultura dengan luas lahan sekitar 94 ribu ha membutuhkan pupuk organik sebanyak 190 ribu ton. Sementara serapan pupuk organik untuk kedua jenis tanaman tersebut baru mencapai 624 ribu ton. Secara rata-rata, nilai tersebut baru menyerap 20\% kebutuhan pupuk. Hal tersebut secara lengkap diperlihatkan pada Tabel 1.

Dengan data-data ini maka diperlukan pengembangan penggunaan pupuk organik dalam usaha mengembangkan pertanian organik. Salah satu caranya adalah dengan melakukan pengembangan industri kecil yang memroduksi pupuk organik dengan memanfaatkan limbah yang ada di sekitar lingkungan. Dalam penelitian ini, selain diperkenalkan pupuk organik yang dapat memperbaiki unsur tanah dengan mengolah limbah tertentu pada masyarakat, pendirian industri ini akan menambah penghasilan para petani dan masyarakat sekitarnya.

Oleh karena itu dalam penelitian ini akan dilakukan identifikasi pengembangan industri

Tabel 1. Potensi Kebutuhan Pupuk Organik di Indonesia [3]

\begin{tabular}{|c|c|c|c|c|c|c|c|}
\hline \multirow[b]{2}{*}{ No } & \multirow[b]{2}{*}{ Provinsi } & \multicolumn{2}{|c|}{ Luas Areal (ha) } & \multicolumn{3}{|c|}{ Potensi Kebutuhan (ton) } & \multirow[b]{2}{*}{$\begin{array}{l}\text { Serapan } \\
\text { (ton) }\end{array}$} \\
\hline & & $\begin{array}{c}\text { Tanaman } \\
\text { Pangan }\end{array}$ & $\begin{array}{l}\text { Horti- } \\
\text { kultura }\end{array}$ & $\begin{array}{c}\text { Tanaman } \\
\text { Pangan }\end{array}$ & $\begin{array}{l}\text { Horti- } \\
\text { kultura }\end{array}$ & Total & \\
\hline 1 & Sumatera Barat & 52.542 & 330 & 26.271 & 660 & 26.931 & 5.386 \\
\hline 2 & Sumatera Selatan & 99.240 & 110 & 49.620 & - & 49.840 & 9.968 \\
\hline 3 & Jawa Barat & 173.700 & 1.660 & 86.850 & 3.320 & 90.170 & 18.034 \\
\hline 4 & Jawa Tengah & 1.732 .626 & 23.017 & 866.313 & 46.034 & 912.347 & 182.469 \\
\hline 5 & Jawa Timur & 2.689 .947 & 56.199 & 1.344 .974 & 112.398 & 1.457 .372 & 291.474 \\
\hline 6 & Kalimantan Selatan & 81.875 & 556 & 40.938 & 1.118 & 42.056 & 8.411 \\
\hline 7 & Nusa Tenggara Barat & 18.375 & 8.160 & 91.875 & 16.320 & 108.195 & 21.639 \\
\hline \multirow[t]{2}{*}{8} & Sulawesi Selatan & 583.000 & 4.305 & 426.500 & 8.610 & 435.110 & 87.022 \\
\hline & Total & 5.431 .305 & 94.337 & 2.933 .341 & 188.680 & 3.122 .021 & 624.403 \\
\hline
\end{tabular}


kecil pupuk organik di daerah tertentu dengan memanfaatkan potensi limbah yang ada di daerah tersebut. Limbah tersebut merupakan limbah yang berasal dari sektor perkebunan, peternakan maupun industri.

\section{METODE PENELITIAN}

Penelitian dilakukan di 2 (dua) daerah yang berbeda karena pertimbangan sumber bahan baku yang akan digunakan dalam pembuatan pupuk organik padat maupun cair. Di kedua lokasi, penelitian dilakukan secara integratif untuk dapat menghasilkan jawaban dari permasalahan yang ditemukan. Penggambaran langkah-langkah penelitian diperlihatkan pada Gambar 1.

Kedua lokasi penelitian berada di Kabupaten Cianjur dan Kabupaten Bogor. Kecamatan Sukanagara, Kabupaten Cianjur adalah salah satu daerah di Provinsi Jawa Barat. Di lokasi ini terdapat perkebunan teh yang dikelola oleh PTPN VIII seluas 1.243 ha. Selain tanaman teh yang ada, terdapat beberapa tanaman yang tumbuh di sekitar pohon teh. Jika dibiarkan, tanaman-tanaman ini akan menjadi parasit bagi tanaman teh karena mengambil hara tanah yang dibutuhkan tanaman teh. Tumbuhan-tumbuhan ini akan menjadi limbah perkebunan setelah petani teh melakukan perawatan kebun teh. Sedangkan di Kecamatan Cisarua, Kabupaten Bogor terdapat peternakanpeternakan sapi yang menghasilkan limbahlimbah peternakan seperti kotoran padat dan cair. Perlu dilakukan penelitian di 2 (dua) lokasi ini dalam pemanfaatan limbah-limbah tersebut menjadi pupuk organik. Selain limbah-limbah tersebut dapat dimanfaatkan menjadi pupuk organik, terbuka pula peluang pengembangan usaha pupuk organik yang dapat menambah penghasilan masyarakat di sekitar lokasi penelitian. Dalam penelitian ini, tanaman yang dijadikan media pengujian adalah teh. Produk pupuk organik padat diuji di Balai Penelitian Tanaman Sayur (Balitsa) Lembang, sedangkan pupuk organik cair diuji di Balai Penelitian Tanah (Balittanah) Bogor. Selain itu, pengujian produk pupuk organik padat dalam bentuk Demonstration Plot (demplot) dilakukan di Afdeling DAN IV Perkebunan Panyairan PTPN VIII Kabupaten Cianjur, sedangkan pengujian produk pupuk organik cair di Afdeling GM1 Perkebunan Gunung Mas PTPN VIII Kabupaten Bogor.

\section{HASIL DAN PEMBAHASAN}

Untuk pupuk organik padat, bahan baku utama yang dibutuhkan terdiri atas hijauan, kotoran hewan, serbuk gergaji dan Effectivity Mikro Organisme (EM). Sedangkan bahan penunjangnya adalah abu limbah hasil pembakaran pabrik teh, gula pasir, asam cuka dan air bersih. Kedua bahan baku ini dicampurkan dengan cara dan komposisi tertentu. Sedangkan untuk pupuk organik cair, bahan baku utama yang dibutuhkan adalah urine sapi, tepung Carboxy Metil Selulose

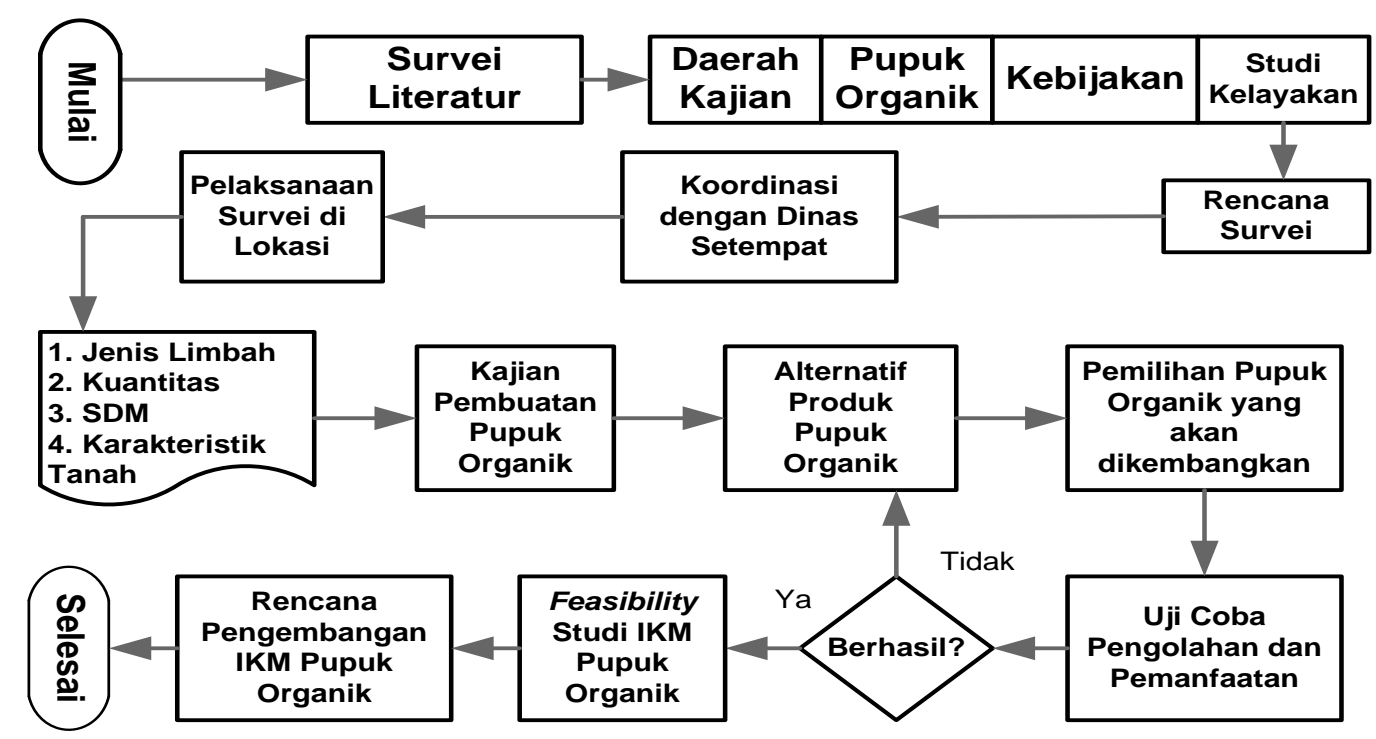

Gambar 1. Langkah-Langkah Penelitian 
Studi Kelayakan Pendirian Industri Kecil Pupuk Organik Padat dan Cair Berbahan Baku Limbah Perkebunan,

Peternakan dan Industri

Rizki Wahyuniardi dan Eeng Sumarna

(CMS) dan EM yang diproses dengan cara dan komposisi tertentu. Seperti dijelaskan sebelumnya, seluruh bahan baku ini tersedia di lokasi pendirian pabrik.

Target pasar dari produk pupuk organik ini ditujukan pada potensi perkebunan di Kabupaten Cianjur yang cukup besar dimana sekitar 19,4\% dari seluruh luas lahannya merupakan areal perkebunan. Perkebunan dikelola oleh Perkebunan Besar Negara (PBN) seluas 10.709 hektar, Perkebunan Besar Swasta (PBS) sekitar 20.174 hektar dan Perkebunan Rakyat (PR) seluas 37.167 hektar. Peningkatan produksi perkebunan, terutama komoditi teh cukup baik. Produktivitas teh rakyat mampu mencapai antara 1.400-1.500 kg teh kering/hektar. Sedangkan yang dikelola oleh perkebunan besar rata-rata mencapai di atas $2.000 \mathrm{~kg}$ per hektar [4]. Dengan kemampuan produksi yang ada, maka target pasar produk ini adalah 156 ton/bulan yang merupakan pemesanan PTPN VIII Nusantara dengan bentuk kemitraan.

Dalam pengolahannya, selain penyediaan bahan baku, pembuatan pupuk organik padat dan cair ini juga memerlukan penyediaan lahan dan bangunan, mesin pengolahan serta tenaga kerja. Untuk pupuk organik padat, kemasan berupa karung dengan berat produk $50 \mathrm{~kg}$ (harga jual Rp. 23.500/karung $\rightarrow$ Rp. 470/kg), sedangkan pupuk organik cair dikemas dalam jerigen dengan isi 20 liter (harga jual Rp. 200.000/jerigen $\rightarrow$ Rp. 10.000/liter) [4]. Total rekapitulasi pembiayaan awal untuk pendirian industri kecil pupuk organik padat dan cair diperlihatkan pada Tabel 2.
Rincian modal tetap untuk kedua industri diperlihatkan pada Tabel 3 dan Tabel 4. Dalam kedua tabel diperlihatkan jenis mesin dan peralatan yang dibutuhkan dalam produksi pupuk organik padat cair.

Tabel 2. Total Biaya Pengembangan Usaha

\begin{tabular}{llrr}
\multirow{2}{*}{ No } & \multirow{2}{*}{ Kelompok } & \multicolumn{2}{c}{ Biaya Pendirian (Rp) } \\
\cline { 3 - 4 } & & \multicolumn{1}{c}{ Padat } & \multicolumn{1}{c}{ Cair } \\
\hline 1. & Modal Tetap & 25.000 .000 & 12.100 .000 \\
2. & Biaya Tetap & 5.000 .000 & 1.000 .000 \\
3. & Biaya Tidak Tetap & 10.000 .000 & 12.650 .000 \\
\hline & Total & 40.000 .000 & 25.750 .000 \\
\hline
\end{tabular}

Jumlah tenaga kerja yang diperlukan untuk pengelolaan industri kecil pupuk organik padat dan cair berturut-turut adalah 9 dan 5 orang. Untuk industri kecil pupuk organik padat, jumlah tersebut terdiri atas 4 orang pengelola sebagai Manajer Pabrik, Kepala Administrasi \& Pemasaran, Kepala Keuangan dan Kepala Produksi sebagai pengelola serta 5 orang operator. Sedangkan untuk industri kecil pupuk organik cair, jumlah tersebut terdiri atas 4 orang pengelola serta 1 orang operator. Upah diberikan secara harian dengan nilai Rp. 50.000 - Rp.70.000 untuk pengelola dan Rp. 30.000 untuk operator. Dengan mempertimbangkan kebutuhan listrik dan air selama satu bulan, maka pada Tabel 5 dan Tabel 6 diperlihatkan rekapitulasi perhitungan harga pokok untuk pupuk organik padat dan cair. Dengan mempertimbangkan biaya yang diperoleh dan harga jual yang dijelaskan sebelumnya, maka perhitungan keuntungan bersih (setelah dikurangi PPN 10\%) dari penjualan masingmasing produk per tahun adalah Rp. 152.852.400 dan Rp. 231.120.000.

Tabel 3. Rincian Modal Tetap untuk Industri Kecil Pupuk Organik Padat

\begin{tabular}{lcccrr}
\hline \multicolumn{1}{c}{ Jenis Aktiva } & Jumlah & Satuan & $\begin{array}{c}\text { Umur } \\
\text { (Tahun) }\end{array}$ & Harga (Rp.) & $\begin{array}{c}\text { Total } \\
\text { Harga (Rp.) }\end{array}$ \\
\hline Mesin Pencacah & 1 & Set & 20 & 12.000 .000 & 12.000 .000 \\
Mesin Mixer & 2 & Set & 20 & 5.000 .000 & 10.000 .000 \\
Timbangan 500 kg & 1 & Set & 20 & 1.200 .000 & 1.200 .000 \\
Plastik terpal & 3 & Set & 2 & 150.000 & 450.000 \\
Gacok & 5 & Set & 2 & 40.000 & 200.000 \\
Termometer & 1 & Set & 1 & 50.000 & 50.000 \\
Sepatu Boot & 5 & Set & 1 & 95.000 & 475.000 \\
Masker & 1 & Set & 1 & 50.000 & 50.000 \\
Sarung tangan & 5 & Set & 1 & 9.000 & 45.000 \\
Embrat & 2 & Set & 2 & 15.000 & 30.000 \\
\hline
\end{tabular}


Tabel 4. Rincian modal tetap untuk industri kecil pupuk organik cair

\begin{tabular}{lcccrr}
\hline \multicolumn{1}{c}{ Jenis Aktiva } & Jumlah & Satuan & $\begin{array}{c}\text { Umur } \\
\text { (Tahun) }\end{array}$ & Harga (Rp.) & \multicolumn{1}{c}{$\begin{array}{c}\text { Total } \\
\text { Harga (Rp.) }\end{array}$} \\
\hline Drum Fermentasi & 10 & Set & 20 & 1.000 .000 & 10.000 .000 \\
Drum Pendinginan & 1 & Set & 20 & 1.000 .000 & 1.000 .000 \\
Sepatu Boot & 5 & Set & 1 & 95.000 & 475.000 \\
Masker & 1 & Set & 1 & 50.000 & 50.000 \\
Sarung tangan & 5 & Set & 1 & 9.000 & 45.000 \\
Saringan & 2 & Set & 2 & 15.000 & 30.000 \\
\hline \multicolumn{2}{r}{}
\end{tabular}

Tabel 5. Rekapitulasi perhitungan harga pokok untuk pupuk organik padat

\begin{tabular}{lrrrrr}
\hline Bulan ke- $^{\prime}$ & 1 & 2 & $3-10$ & \multicolumn{1}{c}{11} & \multicolumn{1}{c}{12} \\
\hline Bahan Langsung (Rp.) $^{*}$ & 46.462 .000 & 46.462 .000 & $\ldots$ & 46.462 .000 & 46.462 .000 \\
Upah Buruh Langsung (Rp.) $_{\text {Upah Tak Langsung (Rp.) }}$ & 3.900 .000 & 3.900 .000 & $\ldots$ & 3.900 .000 & 3.900 .000 \\
Listrik (dalam 1 bulan) & 5.720 .000 & 5.720 .000 & $\ldots$ & 5.720 .000 & 5.720 .000 \\
Air (dalam 1 bulan) & 300.000 & 300.000 & $\ldots$ & 300.000 & 300.000 \\
Total (Rp.) & 200.000 & 200.000 & $\ldots$ & 200.000 & 200.000 \\
Produk yang dihasilkan (kg) & 56.582 .000 & 56.582 .000 & $\ldots$ & 56.582 .000 & 56.582 .000 \\
Biaya per kg (Rp.) & 90.000 & 156.000 & $\ldots$ & 156.000 & 156.000 \\
\hline
\end{tabular}

Tabel 6. Rekapitulasi perhitungan harga pokok untuk pupuk organik cair

\begin{tabular}{lrrrrr}
\hline \multicolumn{1}{c}{ Bulan ke- } & \multicolumn{1}{c}{2} & $3-10$ & \multicolumn{1}{c}{11} & \multicolumn{1}{c}{12} \\
\hline Bahan Langsung (Rp.) * & 14.250 .000 & 14.250 .000 & $\ldots$ & 14.250 .000 & 14.250 .000 \\
Upah Buruh Langsung (Rp.) & 1.000 .000 & 1.000 .000 & $\ldots$ & 1.000 .000 & 1.000 .000 \\
Upah Tak Langsung (Rp.) & 6.600 .000 & 6.600 .000 & $\ldots$ & 6.600 .000 & 6.600 .000 \\
Listrik (dalam 1 bulan) & 300.000 & 300.000 & $\ldots$ & 300.000 & 300.000 \\
Air (dalam 1 bulan) & 200.000 & 200.000 & $\ldots$ & 200.000 & 200.000 \\
Total (Rp.) & 22.350 .000 & 22.350 .000 & $\ldots$ & 22.350 .000 & 22.350 .000 \\
Produk yang dihasilkan (kg) & 3.000 & 4.500 & $\ldots$ & 4.500 & 4.500 \\
Biaya per liter (Rp.) & 7.450 & 4.967 & $\ldots$ & 4.967 & 4.967 \\
\hline *bahan langsung dan pembayaran oleh pemesan dibayarkan setiap tgl 5-8 bulan depannya.
\end{tabular}

Produk hasil pengolahan di kedua industri ini telah diuji di Balitsa Lembang dan Balittanah Bogor serta diujicobakan dalam demplot-demplot yang berada di 2 (dua) lokasi terpisah dan memperlihatkan hasil yang sesuai dengan fungsi pupuk yang diharapkan. Dengan hasil ini, maka validitas produk telah memenuhi kebutuhan tanah yang menjadi persyaratan dalam penggunaan pupuk organik. Kedua produk yang dihasilkan sedang diproses dalam perolehan HAKI.

Setelah dilakukan seluruh kegiatan terhadap aspek-aspek kelayakan suatu usaha, estimasi profitabilitas dari pendirian industri kecil pupuk organik selain berorientasi pada profit, uji kelayakan suatu pabrik secara ekonomi dapat dilihat dari parameter yang telah disampaikan dalam bagian sebelumnya. Hasil perhitungan dari penelitian ini adalah:
1. Modal investasi untuk pendirian industri kecil Pupuk Organik Padat dan Cair berturut-turut adalah sebesar Rp. 56.582.000 dan Rp. 22.350.000.

2. Titik Pulang pokok (Break Event Point) a. Break Event Point pupuk organik padat

- Nilai BEP = Rp. 67.841.129

- $\% \mathrm{BEP}=1,60 \%$

- Kapasitas BEP = 578 Karung

- Tingkat Pengembalian Modal = $438 \%$

- Waktu Kembali Modal (WKM) = 0,23 tahun $=2,75$ bulan

b. Break Event Point pupuk organik cair

- Nilai BEP = Rp. 16.901.408

- $\% \mathrm{BEP}=3,21 \%$

- Kapasitas BEP = 82,26 jerigen

- Tingkat Pengembalian Modal = 938\% 
- Waktu Kembali Modal (WKM) = 0,11 tahun $=1,32$ bulan

3. Internal Rate of Return (IRR) untuk pendirian industri kecil Pupuk Organik Padat dan Cair berturut-turut adalah sebesar $97 \%$ dan $99 \%$.

\section{Pupuk Organik Padat}

Pembuatan pupuk organik ini konstan $60.000 \mathrm{~kg}$. Setiap bahan yang diperam (fermentasi) baru dapat matang dan menjadi pupuk oranik (bokhasi) setelah 10 hari. Artinya dibuat antrian setiap hari masing-masing sebanyak $6.000 \mathrm{~kg}$. Pada hari ke-10 baru dapat dihasilkan pupuk jadi hasil pemeraman hari pertama sebanyak $6.000 \mathrm{~kg}$ pupuk organik. Hari ke-11 diselesaikan pembuatan pupuk jadi hasil pemeraman hari kedua sebanyak $6.000 \mathrm{~kg}$ dan seterusnya hingga hari ke-20. Hari ke-21 telah diproduksi untuk 10 hari berikutnya dan pemeraman ini menjadi hasil produksi bulan berikutnya. Langkah yang dilakukan terdiri atas 3 tahap dengan penjelasan sebagai berikut:

\section{Langkah 1:}

1. Hijauan dicacah, dipotong potong sepanjang $5 \mathrm{~cm}$ sebanyak $1.872 \mathrm{~kg}$

2. Siapkan kotoran domba/sapi sebanyak $5.040 \mathrm{~kg}$

3. Siapkan coklatan (sebuk gergaji) sebanyak $120 \mathrm{~kg}$

4. Siapkan 90 liter air bersih

5. Siapkan 1 liter activator EM4

6. Siapkan terpal penutup fermentasi

Kesemua bahan ini dihitung 115 \% dari pupuk jadi karena penyusutan sebesar 15\% dan masing-masing bahan telah dihitung secara proporsional.

\section{Langkah 2:}

1. Lapisan I, yaitu $2.050 \mathrm{~kg}$ kotoran domba/sapi disiram dengan larutan activator sebanyak 18 liter (membutuhkan waktu selama 100 menit).

2. Lapisan I, dilapisi dengan lapisan II yaitu $936 \mathrm{~kg}$ hijauan disiram dengan larutan activator sebanyak 18 liter (membutuhkan waktu selama 120 menit).

3. Lapisan II ditumpangi dengan lapisan III yaitu 120 kg serbuk gergaji disiram dengan larutan activator sebanyak 18 liter (membutuhkan waktu selama 120 menit)

4. Lapisan III ditumpangi dengan lapisan IV yaitu $936 \mathrm{~kg}$ hijauan disiram dengan larutan activator sebanyak 18 liter (membutuhkan waktu 120 menit)

5. Lapisan IV ditumpangi dengan lapisan terakhir yaitu $2.050 \mathrm{~kg}$ kotoran domba/sapi disiram dengan larutan activator sebanyak 18 liter (membutuhkan waktu selama 12 menit).

6. Semua bahan yang sudah ditumpuk dengan ukuran panjang $5 \mathrm{~m}$, lebar $2 \mathrm{~m}$ dan tinggi 0,5 $\mathrm{m}$ ditutup dengan terpal penutup fermentasi.

\section{Langkah 3:}

1. Setelah 3 hari pemeraman dibalikan dengan merata sehingga menjadi campuran yang homogen (waktu pembalikan atau pencampuran ini membutuhkan waktu 120 menit).

2. Hari ke-4 berikutnya dibalikan dengan lebih merata (proses pembalikkan dibutuhkan waktu 120 menit)

3. Setelah hari ke-10 baru dilakukan pendinginan dan pengarungan (untuk waktu pendinginan membutuhkan waktu 10 menit sedangkan untuk pengepakannya dibutuhkan waktu 600 menit).

Berikut adalah gambar penjadwalan kerja pembuatan pupuk organik. Setiap warna yang berbeda menjelaskan 1 siklus pembuatan pupuk organik. Pada Gambar 2. diperlihatkan siklus pembuatan pupuk dalam 1 bulan. Dengan asumsi 30 hari kerja dalam 1 bulan, diperoleh 15 kali produksi dengan total jumlah produksi sebesar $90.000 \mathrm{~kg} /$ bulan atau 90 ton/bulan. Pada kenyataannya, nilai penyusutan menyebabkan produksi hanya mampu menghasilkan 60.000 $\mathrm{kg} / \mathrm{bulan}$.

\section{Pupuk Organik Cair}

Pembuatan pupuk organik cair ini konstan 150 liter. Setiap bahan yang diperam (fermentasi) baru dapat matang dan menjadi pupuk organik cair (POC) setelah 10 hari. Artinya dibuat antrian setiap hari masingmasing sebanyak 150 liter. Pada hari ke-10 


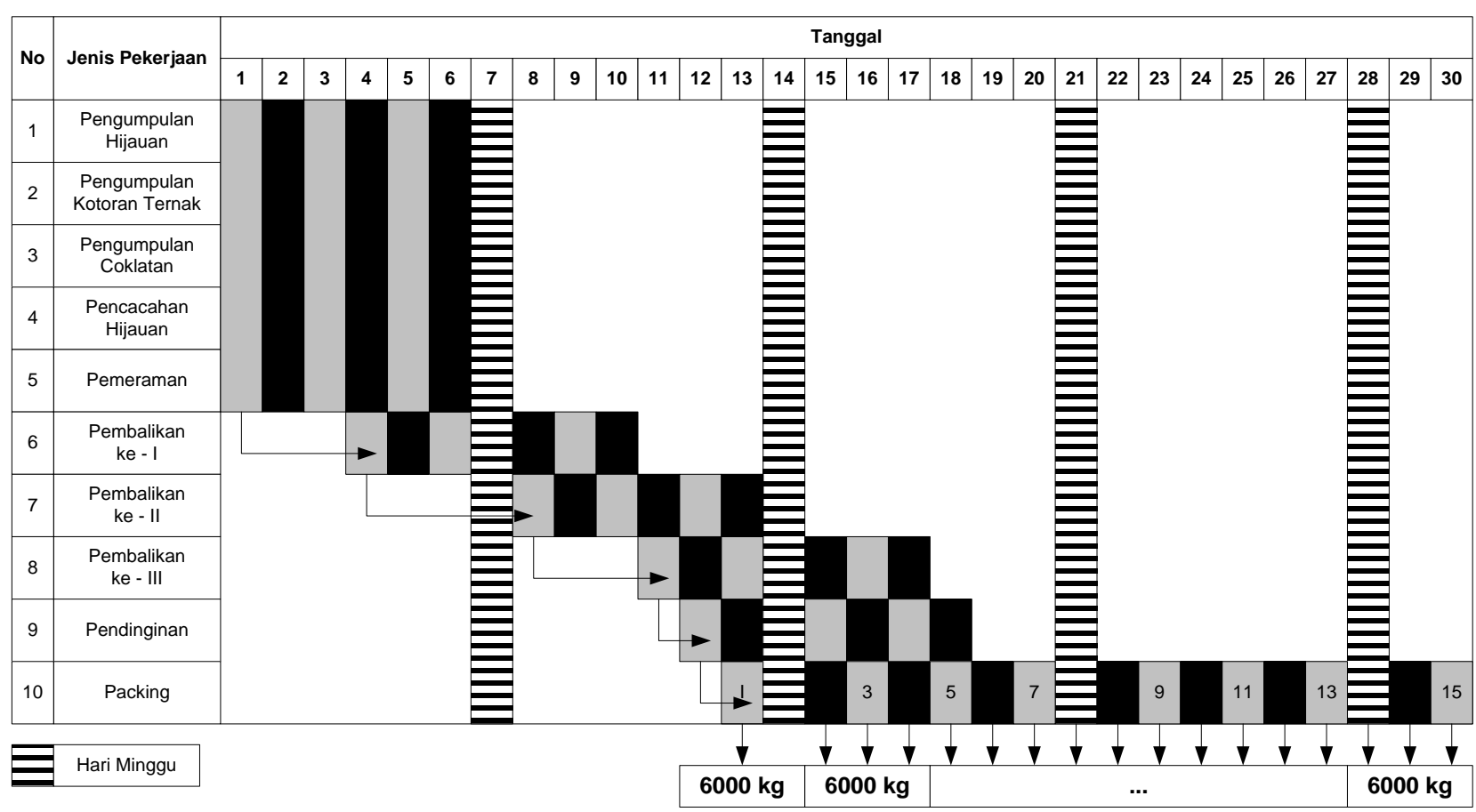

Gambar 2. Langkah dan Jadwal Kerja Pembuatan Pupuk Organik Padat

diselesaikan proses fermentasi, pendinginan (1 hari) di drum pendinginan dan pada hari ke-11 pupuk jadi hasil fermentasi hari pertama sebanyak 150 liter di masukan kedalam kemasan pupuk organik cair. Pada hari ke-12 telah diselesaikan pupuk jadi hasil pemeraman hari kedua sebanyak 1.500 liter dan seterusnya. Fermentasi dilanjutkan dengan antrian berikutnya sebanyak 150 liter setiap hari sampai akhir bulan sehingga akan menghasilkan 4.500 liter setiap bulan.

\section{Langkah 1:}

1. Urine sapi dimasukan ke drum fermentasi sebanyak 150 liter

2. Siapkan tepung CMC sebanyak $2 \mathrm{~kg}$

3. Siapkan EM (Effectivity Mikro Organisme). Kesemua bahan ini diaduk lalu drum ditutup rapat dengan tutup plastik sehingga tidak ada udara yang masuk ke dalam drum selama proses fermentasi berlangsung.

\section{Langkah 2:}

1. Setelah selesai fermentasi, dihari ke-10 pupuk organik cair dimasukan ke drum pendinginan selama 1 hari.

2. Dihari ke-11 pupuk organik cair dimasukan kedalam kemasan.

\section{KESIMPULAN}

Kedua jenis pupuk organik yang dihasilkan ini, berdasarkan pengujian Balitsa Lembang dan Balittanah Bogor, telah memenuhi unsur-unsur kimia yang dipersyaratkan sebagai pupuk organik. Dari penelitian yang telah dilakukan dan berdasarkan perhitungan kelayakan, industri kecil pupuk organik yang menghasilkan dapat menghasilkan 2 (dua) jenis pupuk yaitu pupuk padat dan pupuk cair ini layak untuk dikembangkan. Selain menghasilkan keuntungan bagi industri yang dikembangkan, pengembangan industri kecil pengolah limbah perkebunan, peternakan dan industri ini mampu menghasilkan produk yang sangat berguna bagi perkebunan teh. Selain itu, masyarakat di sekitar perkebunan dapat memperoleh penghasilan tambahan dari pengumpulan limbah yang merugikan pihak perkebunan. Bagi pihak peternak, limbah padat maupun cair dari hewan ternak, pendirian industri kecil pupuk organik akan memberikan nilai ekonomis untuk kotoran yang dihasilkan hewan ternak. Sedangkan bagi pihak industri kerajinan kayu, pendirian industri kecil pupuk organik akan memberikan nilai ekonomis bagi limbah kayu yang dihasilkannya. Secara nasional, penelitian ini berupaya mengimplementasikan Peraturan Menteri 
Studi Kelayakan Pendirian Industri Kecil Pupuk Organik Padat dan Cair Berbahan Baku Limbah Perkebunan,

Peternakan dan Industri

Rizki Wahyuniardi dan Eeng Sumarna

Pertanian No. 2/Pert/Hk.060/2/2006 tentang Pupuk Organik dan Pembenah Tanah.

Dengan besarnya potensi perkebunan yang ada di Indonesia, pendirian industri kecil pupuk organik padat maupun cair di sekitar perkebunan yang ada di seluruh wilayah di Indonesia dapat terus dilakukan dengan memperhatikan potensi limbah yang ada. Penelitian ini telah memperlihatkan salah satu peluang pendirian industri kecil pupuk organik padat dan cair yang sangat potensial untuk dikembangkan di seluruh wilayah di Indonesia, khususnya untuk perkebunan teh. Untuk komoditi lainnya, kerjasama antara Dinas Pertanian Provinsi ataupun Kota/Kabupaten setempat dengan Perguruan Tinggi dalam melakukan penelitian mengenai kesesuaian antara limbah yang ada dan pengembangan industri pupuk organik yang sesuai dengan kebutuhan perkebunan setempat merupakan langkah penting untuk dilakukan.

\section{DAFTAR PUSTAKA}

[1] Prihandarini, Ririen, Potensi Pengembangan Pertanian Organik, 2009, www.maporina.com, diakses Januari 2012.

[2] Suriadikarta, Didi A., R.D.M. Simanungkalit, 2006, Pupuk Organik dan Pupuk Hayati, Balai Besar Litbang Sumberdaya Pertanian, Bogor.

[3] PT Petrokimia Organik (Petroganik), 2012.

[4] Sekilas Diakses pada http: //www .cianjurkab.go.id . 